\title{
Resonance, contextual overlap and goal reactivation: the case of subgoal-related contextual cues
}

Catherine Jovet, Jean-Baptiste Légal, Sandra Jhean-Larose and Guy Denhière

\section{(2) OpenEdition}

\section{Journals}

Electronic version

URL: http://journals.openedition.org/cpl/3273

DOI: $10.4000 / \mathrm{cpl} .3273$

ISSN: $1379-6100$

Publisher

Centre PsyCLÉ

\section{Electronic reference}

Catherine Jovet, Jean-Baptiste Légal, Sandra Jhean-Larose and Guy Denhière, « Resonance, contextual overlap and goal reactivation: the case of subgoal-related contextual cues », Current psychology letters [Online], 23, Vol. 3, 2007 | 2007, Online since 21 December 2007, connection on 08 September 2020. URL : http://journals.openedition.org/cpl/3273 ; DOI : https://doi.org/10.4000/cpl. 3273

This text was automatically generated on 8 September 2020

(c) All rights reserved 


\title{
Resonance, contextual overlap and goal reactivation: the case of subgoal-related contextual cues
}

\author{
Catherine Jovet, Jean-Baptiste Légal, Sandra Jhean-Larose and Guy \\ Denhière
}

What happens when textual information previously processed appears again or is needed for comprehension? In other words, how information in long term memory is (re)activated for possible integration with information that is currently available in working memory? This issue has been explored in the framework of the memory-based text processing view (Gerrig \& McKoon, 1998; Gerrig \& O'Brien, 2005; McKoon, Gerrig, \& Greene, 1996; McKoon \& Ratcliff, 1995) and of the resonance model_(Myers \& O'Brien, 1998; O'Brien \& Myers, 1999). This paper aims to provide a further test of the role of resonance process in the reactivation of goal related information during reading.

The memory-based view states that narrative comprehension is primarily influenced by memory retrieval processes that operate automatically. According to this position, concepts and propositions currently processed in working memory (WM) provide retrieval cues for concepts and propositions stored in long term memory (LTM). According to the resonance model (Myers \& O'Brien, 1998; O'Brien \& Myers, 1999), retrieval of information in LTM is supposed to be accomplished through a "fast-acting, passive resonance process" (Cook, Halleran, \& O'Brien, 1998, pp. 110) This model is based on the assumption that concepts from the discourse representation and general world knowledge resonate as a function of the degree of overlap of semantic and contextual features among concepts. According to the resonance model, resonance is a necessary condition for those memory elements to become available. Thus, resonance helps the reader to build of a coherent discourse representation.

Critical aspects of the resonance process

Three critical aspects of the resonance process can be extracted from the resonance model (Myers \& O'Brien, 1998, O'Brien \& Myers, 1999, see also Lorch, 1998). First, it is passive, automatic. In other words, the resonance process is rapid, irrepressibly 
triggered by contextual cues and out of reader's control. Second, it is "dumb". Information that resonates sufficiently is returned in the working memory, regardless of whether that information is necessary or relevant to the understanding of the currently processed sentence. In other words, the resonance process does not differentiate information that shares features and is relevant to the currently processed sentence from information that shares features but is not relevant. Finally, the resonance process is unrestricted. Any concept in LTM that shares features with the content of WM would resonate.

Factors influencing the resonance process: contextual overlap and degree of elaboration of contextual cue in memory

O'Brien and Myers (1999) presented an overview of the empirical studies investigating the reactivation of concepts during reading. Among the variables governing the reactivation, were the degree of featural overlap and the degree of elaboration of the contextual cue in memory (Albrecht and Myers, 1995; 1998).

Degree of contextual overlap

Within the memory-based text processing framework, featural overlap is considered as a major factor influencing the resonance process: without featural overlap, reactivation should not occur. Specifically, Albrecht and Myers $(1995,1998)$ have demonstrated that the degree of featural overlap can either increase or decrease the probability and the speed with a character's goal resonates and is reactivated. In Albrecht and Myers (1995) studies, participants read texts in which a character's goal was satisfied or unsatisfied. Goal information was then backgrounded by several sentences of filler text. The filler section ended with a context reinstatement sentence, which provided either a contextual overlap or no contextual overlap with the goal information from the backgrounded goal context. The overlap consisted in the repetition of a cue (e.g., leather chair) that had first been mentioned in the original goal context. This sentence was followed by two target sentences. When the goal was unsatisfied, these sentences provided an inconsistency. Results indicated that readers noticed inconsistencies only when the texts contained a contextual overlap (i.e., the repetition of a cue that had previously been mentioned in the original goal context) that reactivated the goal information. As a consequence, reading times on the two target sentences were longer in unsatisfied goal conditions than in satisfied goal conditions. However, the reactivation goal information do not systematically influence comprehension of the target sentence (Guéraud \& Tapiero, 2001; Long \& Chong, 2001)

Degree of elaboration of contextual cue in memory

In a set of experiments, Albrecht and Myers (1998) found that the more the contextual cue was elaborated in the goal context, the faster the unsatisfied goal was reactivated (for further evidence that the elaborated antecedent is more quickly retrieved than was unelaborated antecedent, see O'Brien, Albrecht, Hakala, \& Rizzella, 1995). The degree of elaboration of the contextual cue depended on whether or not an adjectival modifier (e.g., "leather") was associated to the cue (e.g., "chair") in the goal section. Thus, contextual cue was considered as "elaborated" (e.g., "leather chair") when it was associated to an adjectival modifier and "unelaborated" (e.g., "chair") when presented alone. Each text included a contextual overlap that consisted in the repetition of an elaborated contextual cue (i.e., adjectival modifier + noun) or an unelaborated cue (i.e., noun) that was previously mentioned in the original goal context. Results demonstrated that readers detect inconsistencies in the elaborated and unelaborated 
contextual cue conditions. Reading times on target sentences were longer when the goal was unsatisfied than when it was satisfied. Nevertheless, when the contextual cue was unelaborated, this effect appeared only for the second target sentence. Albrecht and Myers (1998) explain this time increase by the reactivation of the unsatisfied goal. The reactivation would be triggered by the processing of contextual cues (elaborated or unelaborated) that would lead readers to detect the inconsistency. According to the results, an unelaborated contextual cue was sufficient to reactivate the unsatisfied goal, but the reactivation was slower. In sum, these findings put in light that resonance process is sensitive to both contextual overlap (for its triggering) and to the degree of elaboration (for its intensity and speed).

Causal structure of narratives

The causal structure of narratives is another important factor in text comprehension. Particularly, it has been demonstrated that causal structure may influence the ease in which information can be accessed. For instance, causal structure affects the processing of causal relations and memory representation of these relations (Caillies, Denhière \& Kintsch, 2002; Caillies, Denhière, \& Jhean-Larose, 1999; Suh \& Trabasso, 1993; Trabasso, van den Broek \& Suh, 1989; Trabasso \& van den Broek, 1985; van den Broek \& Lorch, 1993). The representation of causal relations in narratives can be described either as a linear chain or as a network. The linear chain model assumes that readers attempt to establish causal connections only between events in adjacent sentences in the surface structure of the text (Black \& Bower, 1980; Fletcher \& Bloom, 1988). According to this model, only these relations would be included in readers' memory representation of the text. In contrast, the causal network model assumes that multiple connections are possible to a single event. Readers will establish causal connections between events in nonadjacent as well as in adjacent sentences in the surface structure of the text. So, both relations would be represented. Moreover, within the causal network, the retrieval could be function of the presence or not of a direct causal relation between events in the memory representation. In other words, retrieval could be function of the strength of the relation linking events together (Lutz \& Radvansky, 1997; Magliano \& Radvansky, 2001; van den Broek \& Lorch, 1993). As causal structure is known to affect the retrieval of the stored information from long term memory, one can assumed that causal structure, combined with contextual overlap, could facilitate or impede the resonance process.

Overview and predictions

In two experiments, we explored the effects of a new contextual overlap manipulation on the resonance process. Specifically, we considered contextual overlap in association with the text's temporo-causal structure. We constructed 8 narratives on the basis of the ones used by Albrecht and Myers (1995, 1998). First, an introduction presented the character and his/her goal. In the next section, information were given about satisfaction or non satisfaction of this goal. Then, took place a filler section ending with a reinstatement sentence that featured a contextual overlap. The narrative ended with two target sentences (that could be perceived as consistent or inconsistent, depending on the fact that the main goal was satisfied or not (i.e., inconsistency paradigm) and a small conclusion.

The main difference with Albrecht and Myers' texts concerns the fact that we introduced a specific temporo-causal structure (i.e., a fixed goal-subgoals sequence) to subsequently set up a specific manipulation of the contextual overlap. Thus, after the presentation of the character's goal, three successive subgoals were introduced. These 
subgoals were performed by the character in order to achieve his/her main goal. We manipulated the contextual overlap in regard to this specific temporo-causal structure. More precisely, the cue used to produce the overlap (i.e., the repetition of words presented earlier in the text) could either be associated with a subgoal close or distant from goal attainment in the causal structure (Note that the terms close and distant must be considered as a function of goal attainment and not of the respective position of the cues in the text).

In line with the memory-based processing view (Myers \& O'Brien, 1998; O'Brien \& Myers, 1999), we assumed an effect of the goal satisfaction: reading times on the target sentences should be longer when a goal had previously been unsatisfied than when it had been satisfied, reflecting the detection of inconsistency. In addition, we assumed a main effect of contextual overlap on target sentences reading times. If, as we hypothesised, the manipulation of contextual overlap in terms of origin of the cue in the temporo-causal structure, leads to a difference in terms of reactivation, reading times on the target sentences should be longer when the contextual cue appeared earlier in a subgoal close rather than distant of the goal attainment. Finally, as a close overlap is assumed to produce a greater goal reactivation, we supposed that the inconsistency effect should be greater in the close overlap condition than in the distant overlap condition.

Another purpose was to investigate the effect of the contextual overlap on the reading times of the context reinstatement sentence. Indeed, if the resonance process is automatic, goal information that was associated with the contextual cue in the goal context should immediately resonate in response to the processing of the reinstatement sentence. Accordingly, an effect of contextual overlap could also be obtained on the reinstatement sentences. Reading times on the reinstatement sentence could be shorter when it features a close rather than a distant overlap.

Experiment 1

The aim of the experiment was to determine to what extent a specific contextual overlap, in association with text's temporo-causal structure, could affect the resonance process. Exploration of the manipulation of this factor took place in an inconsistency detection paradigm. Texts were constructed in respect with the structure of narratives used by Albrecht and Myers (1998). Stories described a goal that a character wanted to complete and three successive actions corresponding to subgoals performed by the character in order to achieve his/her main goal. As in Albrecht and Myers (1998), target sentences varied in consistency with respect to the goal satisfaction. They were consistent when the character had achieved his/her main goal, but were inconsistent when the character had not satisfied this goal. The goal satisfaction was manipulated so that the main goal could either be satisfied (completed) or unsatisfied (not completed but still needing to be completed). We also manipulated the contextual overlap between the reinstatement sentence and a specific subgoal of the sequence of goal attainment. This factor was manipulated as a function of the distance between the subgoal from which was extracted the contextual cue and the statement of the goal attainment in the temporo-causal structure of the texts. Distance corresponds here to the temporal distance separating a subgoal from the goal attainment. So, the temporal subgoal 3 was close to goal attainment statement but distant from the sentence 
introducing the goal in the text surface structure. In contrast, the temporal subgoal 1 was distant from goal attainment but close to the goal statement. In line with Albrecht and Myers, our materials included a high contextual overlap, that is the repetition of a contextual cue elaborated earlier in the text. Contextual overlap was manipulated as a function of the "subgoal" from which was extracted the contextual cue used in the context-reinstatement sentence. In the close contextual overlap condition, the context reinstatement sentence introduced an overlap that consisted in the repetition of a contextual cue that previously appeared in a subgoal close to the goal attainment (i.e., Subgoal 3). The distant overlap condition introduced an overlap that consisted in the repetition of a cue that previously appeared in a subgoal distant to the goal attainment (i.e., Subgoal 1).

The resonance model proposes that when a contextual overlap occurs, goal information resonates and is reactivated. As the two versions of reinstatement sentence provide an overlap, the goal information should resonate and become accessible for processing during the reading of the first target sentence in both close and distant overlap conditions. In any case, the repetition of a contextual cue that previously appeared in a subgoal should reactivate this subgoal as well as the goal associated with the subgoal. In addition, we assume that the extent in which the goal will resonate will be a function of the goal-subgoals structure and of the strength of the connexions between the activated goal and the contextual cues within this structure. In sum, we assume that such a manipulation of the contextual overlap should have an influence on the extent to which the goal will resonate and become reactivated. Indeed, subgoal 3 temporally close of goal attainment- should be more strongly connected with the sentence introducing the character's goal than subgoal 1 - temporally distant of goal attainment. So, goal information should be more easily (re)activated by the processing of contextual cue extracted from subgoal 3 (close overlap) than from subgoal 1 (distant overlap). In both cases, the reactivation process triggered these contextual cues should lead the readers to notice the inconsistency in the target sentences, resulting in an additional processing of these sentences. Nevertheless, according to our hypothesis about contextual overlap, the slowdown in reading of the target sentences following an unsatisfied goal should be greater in the close overlap than in the distant overlap condition.

In addition, on the basis of the assumption of a "dumb" resonance process, we hypothesized that the goal should resonate and become reactivated in both satisfied and unsatisfied goal versions of the texts. Indeed, in presence of an overlap, the goal should resonate regardless of whether it has been satisfied or not. However, the satisfied goal (consistent with the target sentences) should be easily integrated with the information already activated in working memory, whereas the unsatisfied goal (inconsistent with the target sentences), should lead the readers to notice the inconsistency, resulting in comprehension difficulties and additional information processing.

MethodParticipants.

Participants were 44 students of University of Paris 10. Their participation was volunteer and they did not receive course credit for their involvement in the experiment. All of them were native French speakers.

Materials. 
In respect with the structure of texts used in past investigations (Albrecht and Myers, 1995; 1998), eight narratives were constructed (A translation of one of the text is shown in Appendix). Each passage was composed of five sections: an introduction, a goal section, a filler section, two target sentences, and a conclusion. The introduction presented the main character and the setting. The sixth sentence of the introduction section introduced the goal the character wanted to complete (for example, Nicolas needed to finish to write up the last ten sheet today) and three successive actions corresponding to three subgoals performed by the character in order to try to achieve the desired goal (in the example, subgoal 1: Nicolas opened the blue file; subgoal 2: he underlined the main ideas and subgoal 3: he took index cards out of a metallic locker). This section was followed by the goal section. In this section, the first sentence described an event that occurred before or after the achievement of the main goal. This event reminded the character an alternative goal he/she also had to accomplish. At this point, the goal satisfaction was manipulated. In the unsatisfied goal version, this event occurred before the main goal was achieved and temporarily hindered the goal pursuit. The last sentence of the section stated that the character would resume the pursuit of his/her goal after the alternative goal will be completed. In the satisfied goal version, the event occurred after the main goal achievement, and so, did not interfere with the pursuit of the goal. The following section was a filler section that described actions and events related to the alternative goal pursuit and its achievement. The last sentence of this section, called context reinstatement sentence, introduced a contextual overlap that consisted in the repetition of an elaborated cue appeared earlier either in a subgoal close (i.e., subgoal 3: index cards) or distant (i.e., subgoal 1: blue file) of the main goal attainment. Note that the two contextreinstatement sentence versions made reference to a contextual cue that previously appeared in the text, but never made a direct reference neither to the subgoalnor to the goal. Two target sentences followed the reinstatement sentence. They described the character engaged in actions that were consistent with the satisfied goal but inconsistent with the unsatisfied goal. Finally, the text ended with a two-sentence conclusion.

Design.

We used a 2 (Goal Satisfaction) x 2 (Contextual overlap) within-participants design. Goal satisfaction was combined with contextual overlap to produce four versions of each text: close overlap-satisfied goal, close overlap-unsatisfied goal, distant overlapsatisfied goal and distant overlap-unsatisfied goal. Reading times on the target sentences and the context reinstatement sentence were recorded as dependent measures. Each participant was randomly assigned to the four conditions with two constraints. First, each participant saw two passages in each condition; and second, across participants, each passage occurred in each condition an equal number of times. The order of the passages was the same for all participants.

Procedure.

Each participant individually completed a session that lasted approximately $30 \mathrm{~min}$. All materials were presented on a computer screen. Participants were instructed to place their right thumb on the spacebar key, their right index finger on a "Yes" key, and their left index finger on a "No" key. Participants were instructed to read the texts at their own pace. Each passage began with the display of the word ATTENTION! in the middle of the screen. Participants were instructed to press the spacebar when they 
were ready to read the passage. Once started, each press on the spacebar erased the current line of text and presented the next line. Reading times were recorded for each sentence. After each text, participants answered to two affirmations. These affirmations required participants to assess whether the statement was true or false, based on what they had read in the text. After each response, participants were given a feedback on the validity of their answer. The purpose of this verification task was to check whether or not participants had carefully read the text. The experiment began with two practice texts, to make sure that participants understood well the procedure. Results

We conducted three independent 2 (Goal Satisfaction) x 2 (Contextual Overlap) analyses of variance (ANOVAs): one on reading times for the first target sentence, one on reading time for second target sentence and the last one on reading times for the context reinstatement sentence. Outliers were identified using Tukey's (1977) hinge criterion and replaced in each condition by the mean reading time. This substituted less than $5 \%$ of the reading times. No reliable effects were found on the reading time for the second target sentence. As a consequence, only mean reading times for the target sentence 1 and the context reinstatement sentence are presented in Table 1.

Target sentence 1

There was a significant main effect of contextual overlap on reading times, $F(1,43)=8.61, M S E=122.34, p<.006$. Reading times on the first target sentence were longer in the close overlap condition $(\underline{M}=4005 \mathrm{~ms})$ than in the distant overlap condition $(\underline{M}=3622 \mathrm{~ms})$. The main effect of goal satisfaction was not significant, $F(1,43)=0.28, M S E=121.54$. Planned comparisons also indicated that the difference between these goal conditions in the close overlap condition was not reliable. This was corroborated by an absence of interaction between Satisfaction and Contextual Overlap, $F(1,43)=0.35, M S E=151.47$.

Context reinstatement sentence

We conducted a $2 \times 2$ analyse of variance on reading times for the reinstatement sentence. Goal Satisfaction (satisfied vs. unsatisfied) and Contextual Overlap (close vs. distant) were treated as within-subjects variables. The analysis yielded a main effect of contextual overlap on reading times, $F(1,43)=24.42, M S E=132.79, p<.0001$. Context reinstatement sentences including a close overlap were read slower $(\underline{M}=4059 \mathrm{~ms})$ than sentences that included a distant overlap $(\underline{M}=3447 \mathrm{~ms})$. Again, reading times did not differ in regard of goal satisfaction $F(1,43)=0.02, M S E=129.15$. The interaction was not reliable, $F(1,43)=1.86, M S E=155.58$. 
Table 1. Mean reading times (in milliseconds) and standard deviation (under brackets) for the first target sentence and the context reinstatement sentence as a function of goal satisfaction and contextual overlap.

\begin{tabular}{lccc}
\hline & $\begin{array}{c}\text { Unsatisfied goal } \\
\text { (U) }\end{array}$ & $\begin{array}{c}\text { Satisfied goal } \\
\text { (S) }\end{array}$ & $\begin{array}{c}\text { Difference } \\
\text { (U - S })\end{array}$ \\
\hline Close overlap & \multicolumn{3}{c}{ First target sentence } \\
Distant overlap & $4080(1271)$ & $3932(893)$ & +148 \\
& $3618(977)$ & $3627(877)$ & -9 \\
\hline & & Context \\
& & reinstatement \\
& & sentence & \\
\hline Close overlap & $4134(1020)$ & $3983(1069)$ & +151 \\
Distant overlap & $3353(900)$ & $3541(1139)$ & -188 \\
\hline
\end{tabular}

Discussion

Reading times observed on the first target sentence suggest that readers did not notice the inconsistency between the target sentence and the unsatisfied goal in both contextual overlap conditions. In our study, unlike Albrecht and Myers $(1995,1998)$ findings, goal satisfaction had no impact on the reading time of the first target sentence. Nevertheless, the fact that we did not obtain an inconsistency effect does not mean that the goal information has not been reactivated. Indeed, as demonstrated by Cook, Halleran, and O'Brien (1998) and Long and Chong (2001), reactivation of disconfirmed or irrelevant information do not necessarily influence comprehension of the target sentences. Still, this result is consistent with the description of resonance as an unrestricted, “dumb” process (Myers \& O’Brien, 1998).

Results also indicated that the contextual overlap had an impact on reading times for both the first target sentence and the context-reinstatement sentence. Specifically, the close overlap condition resulted in longer reading times than in the distant overlap condition. Contrary to our hypothesis, the extent to which the goal resonates and becomes reactivated seems independent of the force of connection between the goal and the subgoals from which the contextual cue were extracted. So, a contextual cue associated with a subgoal close of the main goal attainment (subgoal 3) does not increase the speed of retrieval of the goal and even slows it down. We assumed that, in the situation model, the third subgoal (i.e., the closest of the goal attainment in the temporo-causal structure) was more strongly related with the initial goal information than the first subgoal. Nevertheless, it seems that participants, during the reading of the context reinstatement sentence providing a close overlap, did not establish a direct connection between the third subgoal and the initial goal information. On the contrary, rather than being direct this connection would be indirect (i.e., mediated by subgoal 2 and subgoal 1). Thus, the number of steps in the network to attain the initial goal information would be higher from the reactivation of the close subgoal ( 3 steps) than the distant one (1 step). Inversely, when the contextual cue appeared earlier in a subgoal distant of the goal attainment, a direct connection between the subgoal information, associated to the cue, and the goal information would have permit a very rapid access to the goal information. In sum, in the close subgoal condition (subgoal 3), goal information reactivation would involve a longer path (3 steps in the temporal goal subgoals structure). Conversely, in the distant subgoal condition, the connection would be direct between the distant subgoal (subgoal 1) and the goal. This explanation is 
consistent with Albrecht and Myers' proposal that the reactivation of the goal is not direct, but is "mediated by relations established earlier in the text" (Albrecht and Myers, 1995, pp. 1463).

An alternative explanation for the slower reading times in the close overlap condition could be related to a difficulty to integrate the context reinstatement sentence to the immediately preceding filler sentence. If so, reading times variations could be explained by processes involved in achieving local coherence rather than by the resonance process. For instance, local coherence could be weaker between these two sentences in the close overlap condition than in the distant overlap condition. As a consequence, close overlap would lead to longer reading times on the reinstatement sentence. In the experiment 2, we investigated this idea to determine whether the effect of contextual overlap was the result of a local coherence problem or the result of goal reactivation.

Experiment 2

The goal of Experiment 2 was to determine whether the effect of the specific contextual overlap observed in Experiment 1 was due to a greater difficulty to integrate the reinstatement sentence with the last filler sentence in the close overlap condition (i.e., the local coherence hypothesis) or was due to the amount of time required to retrieve the goal by means of the resonance process (i.e., the retrieval hypothesis). In order to test the local coherence and retrieval hypotheses, filler sentences of the narratives were replaced by a nonverbal material: a mental calculus task. As the filler section, this task should allow a complete backgrounding of goal information. Moreover, as the task is totally unrelated with the preceding textual contents as well as with the reinstatement sentence, there is no reason, at the end of the calculus task, that readers attempt to integrate the reinstatement sentence with the current content of the working memory (i.e., information about calculus operations). Because the reinstatement sentence was not related to the information about calculus operations, it is very unlikely that the close overlap condition leads to further integration than the distant overlap condition. In fact, as information about the calculus task is irrelevant to the content of the narrative, no integration should be required. As a result, there is no reason that reading times on the reinstatement sentence would be longer in the close overlap condition.

Predictions concerning the reading times as a function of the contextual overlap differ according to the local coherence and retrieval hypotheses. According to the local coherence hypothesis, the effect of contextual overlap obtained in the experiment 1 (i.e., longer reading times on the reinstatement sentence providing a close overlap) should not occur. Specifically, because the reinstatement sentence was preceded by a same nonverbal material (a mental calculus task), close and distant overlap conditions should be equally unrelated with it. As a result, in the close overlap condition, the completion of the task should have the same influence on reading resumption as in the distant overlap condition. Thus, reading times on the reinstatement sentence should not differ reliably among the overlap conditions. According to the retrieval hypothesis, the variation of reading times on the reinstatement sentences observed in experiment 1 should be replicated. Participants should read the reinstatement sentences more slowly when they provide a close overlap than a distant overlap. If, as we assume, the reading times increase still occurs, then the explanation in terms of integration difficulty could be ruled out. 
Method Participants.

Participants were 40 students of University of Paris 10 . Their participation was volunteer and they did not receive course credit for their involvement in the experiment. All of them were native French speakers.

Materials and Procedure.

Materials and procedure were globally similar to those used in Experiment 1. Texts were the same as in Experiment 1. The only difference concerned the filler sentences that were replaced by a mental calculus task. We designed the mental calculus task so that its accomplishment requires a time similar to the reading of the filler section (i.e., 30 seconds). Concretely, after the reading of the last sentence of the goal section, participants were instructed to mentally resolve a calculus operation (e.g., $50 \times 28+12=$ ?). The task was 30 seconds long in order to remove all textual content from working memory. After the completion of the task, the reading of the text was resumed. At this moment, the context-reinstatement sentence was displayed. Context reinstatement sentences were the same as in experiment 1 and provided a contextual overlap from a subgoal either close or distant of the goal attainment. Importantly, these sentences never made direct reference to the subgoal nor to the goal. Then target sentences and the conclusion section were displayed. As in the experiment 1, after each text, participants answered two questions about the story.

Results

We performed two ANOVAs, the first on reading times for the context reinstatement and the second on reading times for the first target sentence. Goal Satisfaction (satisfied vs. unsatisfied) and Contextual Overlap (close vs. distant) were treated as within-subjects variables. As in experiment 1 , outliers were identified using Tukey's (1977) hinge criterion and replaced in each condition by the mean reading time. This substituted less than $6 \%$ of the reading times.

Reinstatement sentence.

The analysis yielded a main effect of the contextual overlap, $F(1,39)=5.15$, MSE $=$ $314.59, p=.028$. (see Table 2 ). As in Experiment 1, participants read the reinstatement sentence more slowly when it provided a close overlap $(\underline{\mathrm{M}}=6442 \mathrm{~ms})$ than a distant overlap $(\underline{M}=5752 \mathrm{~ms})$. There was no main effect of goal satisfaction $F(1,39)=0.49$, MSE $=328.61$ and no Goal satisfaction $x$ Contextual Overlap interaction $F(1,39)=2.92, M S E=$. 384.22 .

Target sentence 1 .

The main effect of contextual overlap on reading times for the target sentence 1 was significant, $F(1,39)=4.49, M S E=224.05, p=.04$. Reading times in the close overlap condition were longer $(\underline{M}=4268 \mathrm{~ms})$ than those in the distant overlap condition $(\underline{\mathrm{M}}=$ $3910 \mathrm{~ms}$ ). In addition, the main effect of the goal satisfaction did not reach the significance criteria, $F(1,39)=3.93 ; M S E=238.47$. Reading times tended to be longer when the goal had not been satisfied $(\underline{M}=4325 \mathrm{~ms})$ than when it had been satisfied $(\underline{M}=$ $3853 \mathrm{~ms})$. The interaction of the factors was not significant $F(1,39)=0.33, M S E=$. 258.08. 
Table 2: Mean reading times (in milliseconds) and standard deviation (under brackets) for the context reinstatement sentence and the first target sentence as a function of goal satisfaction and contextual overlap.

\begin{tabular}{lccc}
\hline & $\begin{array}{c}\text { Unsatisfied goal } \\
\text { (U) }\end{array}$ & $\begin{array}{c}\text { Satisfied goal } \\
\text { (S) }\end{array}$ & $\begin{array}{c}\text { Difference } \\
\text { (U - S })\end{array}$ \\
\hline Close overlap & \multicolumn{3}{c}{ Context reinstatement sentence } \\
Distant overlap & $6803(2881)$ & $6080(2031)$ & +723 \\
& $5645(2221)$ & $5860(2586)$ & -215 \\
\hline Close overlap & \multicolumn{4}{c}{ Target sentence 1 } \\
Distant overlap & $4537(1975)$ & $4000(1588)$ & +537 \\
\hline
\end{tabular}

Discussion

The purpose of this second experiment was to distinguish among two explanations in regard to the increase on reading times of the reinstatement sentence when it featured a close overlap. According to the integration difficulty hypothesis, participants should not have spent more time to read reinstatement sentences introducing a close overlap than a distant overlap. Indeed, in this study, context reinstatement sentences in both overlap conditions were equally unrelated with the content of the working memory (information about calculus operations). As a result, according to this hypothesis, no significant reading times difference between the close and the distant overlap conditions should have been obtained. However, results indicate an increase in reading times for the reinstatement sentence in the close overlap condition. So, we can conclude that the local coherence hypothesis cannot accountfor the observed time increase.

Finally, the slowdown on reading times in the close overlap condition, observed in both experiments, provides further support to the retrieval hypothesis. So it seems that, when the close overlap was present, it reactivated the character's goal, and this resulted in longer reading times for the reinstatement sentences. In other words, results suggest that the contextual overlap produce an effect on the resonance process at an early stage: the processing of the context reinstatement sentence.

General Discussion

In two studies, we investigated whether the resonance and the reactivation of a goal previously stated in a text is affected by a specific contextual overlap: the repetition of a close vs. a distant subgoal-related contextual cue. In previous research, manipulation of contextual overlap depended on the presence (or not), in the context reinstatement sentence, of a contextual cue that previously appeared in the goal context and/or on whether this cue was fully or partially repeated (Albrecht and Myers, 1995; Albrecht and Myers, 1998). Our experiments extended these researches in manipulating contextual overlap in regard of temporal-causal structure of the narratives. Narratives were composed of a goal and three successive subgoals performed in order to reach the goal and contextual overlap was manipulated as a function of the distance (close vs. distant) between the subgoal from which was extracted the contextual cue and attainment of the goal in the temporal-causal structure. We assumed that, within the temporal-causal structure, subgoal 3 would be more strongly related to the goal than subgoal 1, and that, as a consequence, goal information would be more rapidly reactivated by the processing of a contextual cue from subgoal 3 than from subgoal 1 . 
Given these assumptions, we expected that the nature of this specific overlap, related to the goal-subgoals structure of the narratives, could have a particular effect on the resonance process.

In experiment 1 , participants spent more time to read the first target sentence when it was preceded by a context reinstatement sentence introducing a close overlap than introducing a distant overlap. This increase of reading times occurred regardless of goal satisfaction. If these results may seem odd in regard of the inconsistency detection hypothesis (i.e., longer reading times when the goal is unsatisfied than satisfied), they are however highly consistent with the characterization of retrieval as an unrestricted, dumb, resonance process (Myers \& O'Brien, 1998; O'Brien \& Myers, 1999): all backgrounded concepts that share features with information in working memory resonate, independently of their relevance to the content of working memory. In our view, the fact that reading times did not differ reliably as a function of goal satisfaction suggest that the resonance process is triggered by a contextual overlap but also that it operates independently of the goal satisfaction. In other words we think that, in presence of an identical overlap, the goal resonates, regardless of its satisfied or unsatisfied status.

Interestingly, we found that participants were slower to read the context reinstatement sentence when it contained a contextual cue that previously appeared in a subgoal that was close from goal attainment (close overlap condition) than distant from goal attainment (distant overlap condition). Thus, it seems that the contextual overlap and, specifically, an overlap linked to the goal-subgoals structure of narratives, may have an impact on the speed of the resonance process. Depending on the type of contextual overlap, goal resonance could be more or less immediate. The interpretation of the effect obtained on the context reinstatement sentence reading times gave rise to two main explanations. The first referred to a difficulty of integration of the context reinstatement sentence (local coherence hypothesis), the second referred to differences in terms of goal information retrieval or resonance speed (retrieval hypothesis).

Results of experiment 2 provided evidence in favour of the retrieval hypothesis, indicating that the time increase is more likely explained by differences in terms of retrieval. However, even if our data indicate that goal retrieval and reactivation account for the observed time increases, processes need to be further explored and explained.

Taken as a whole, results indicated that the reading of the reinstatement sentence reactivates the goal of a character, independently of the nature of the material included between the goal section and the context reinstatement sentence and independently of the goal status. It also indicated that the nature of contextual overlap, relatively to the text structure, seems to influence the re-activation of a goal formerly presented in a text.

Finally, results stress the importance of the contextual overlap in the resonance process and highlight the importance of the temporo-causal structure of the text in the manipulation of this factor. In that sense, it provides new information about overlap in the resonance framework and raise new research questions. Particularly, it could be fruitful, for the future research, to explore further the relations between text causal and temporal structure, overlap and resonance. 


\section{BIBLIOGRAPHY}

Albrecht, J. E., \& Myers, J. L. (1995). The role of context in the accessibility of goals during reading. Journal of Experimental Psychology: Learning, Memory, and Cognition, 21, 1459-1468.

Albrecht, J. E., \& Myers, J. L. (1998). Accessing distant text information during reading: Effects of contextual cues. Discourse Processes, 26, 87-107.

Black, J. B., \& Bower, G. H. (1980). Story understanding as problem solving. Poetics, 9, 223-250.

Caillies, S., Denhière, G., \& Kintsch, W. (2002). The effect of prior knowledge on understanding from text: Evidence from primed recognition. European Journal of Cognitive Psychology, 14, 267-286.

Caillies, S. Denhière, G., \& Jhean-Larose, S. (1999). The intermediate effect: Interaction between prior knowledge and text structure. In H. van Oostendorp \& S. Goldman (Eds.), The construction of mental representation during reading (pp. 151-168). Hillsdale, NJ: Lawrence Erlbaum Associates, Inc.

Cook, A. E., Halleran, J. G., \& O'Brien, E. J. (1998). What is readily available during reading? A memory-based view of text processing. Discourse Processes, 26, 109-129.

Fletcher, C. R., \& Bloom, C. P. (1988). Causal reasoning in the comprehension of simple narrative texts. Journal of Memory and Language, 27, 235-244.

Gerrig, R. J., \& McKoon, G. (1998). The readiness is all: the functionality of memory-based text processing. Discourse Processes, 26, 67-86.

Gerrig, R. J., \& O'Brien, J. (2005). The scope of Memory-based processing. Discourse processes, 39, 225-242.

Guéraud, S., \& Tapiero, I. (2001). Construction d'une représentation cohérente en mémoire : Influence de la valence des informations textuelles sur le processus de résonance, In Cognito, 23, 51-60.

Long, D. L., \& Chong, J. L. (2001). Comprehension skill and global coherence: A paradoxical picture of poor comprehenders' abilities. Journal of Experimental Psychology: Learning, Memory, and Cognition, 27, 1424-1429.

Lorch, R. F. (1998). Memory-based text processing: assumptions and issues. Discourse processes, 26, 213-221.

Lutz, M. F., \& Radvansky, G. A. (1997). The fate of completed goal information in narrative comprehension. Journal of Memory and Language, 36, 293-310.

Magliano, J. P., \& Radvansky, G. A. (2001). Goal coordination in narrative comprehension. Psychonomic Bulletin \& Review, 8, 372-376.

McKoon G., Gerrig, R. J., \& Greene, S.B. (1996). Pronoun resolution without pronouns: Some consequences of memory-based text processing. Journal of Experimental Psychology: Learning, Memory, and Cognition, 22, 919-932.

McKoon, G., \& Ratcliff, R. (1995). The minimalist hypothesis: Directions for research. In C.A. Weaver, S. Mannes, \& C. R. Fletcher (Eds.), Discourse comprehension: Essays in Honor of Walter Kintsch (pp. 97-116). Hillsdale : Lawrence Erlbaum Associates.

Myers, J. L., \& O'Brien, E. J. (1998). Accessing the discourse representation during reading. Discourse Processes, 26, 131-157. 
O'Brien, E. J., \& Myers, J. L. (1999). Text comprehension: A view from the bottom up. In S. R. Goldman, A. C. Graesser \& et al. (Eds.), Narrative comprehension, causality, and coherence: Essays in honor of Tom Trabasso (pp. 35-53). Mahwah: Lawrence Erlbaum Associates.

O'Brien, E. J., Rizzella, M. L., Albrecht, J. E., \& Halleran, J. G. (1998). Updating a situation model: A memory-based text processing view. Journal of Experimental Psychology: Learning, Memory, \& Cognition, 24, 1200-1210.

Suh, S., \& Trabasso, T. (1993). Inferences during reading: convergence evidence from discourse analysis, talk-aloud protocol, and recognition priming. Journal of Memory and Language, 32, 279-300.

Trabasso, T., \& van den Broek, P. (1985). Causal thinking and the representation of narrative events. Journal of Memory and Language, 24, 612-630.

Trabasso, T., van den Broek, P., \& Suh, S. (1989). Logical necessity and transitivity of causal relations in stories. Discourse Processes, 12, 1-25.

Tukey, J. W. (1977). Exploratory data analysis. Reading, MA: Addison-Wesley.

van den Broek, P., \& Lorch, R. F. (1993). Network representations of causal relations in memory for narrative texts: Evidence from primed recognition. Discourse Processes, 16, 75-98.

\section{APPENDIXES}

\section{Example of a text translate in English}

Text 1.

Introduction. Nicolas is an undergraduate student. He studies history at the University of Paris. He is fascinated by music and belongs to a rock group. Nicolas was very conscientious and never missed a course. His exam was due in five days' time, he intended to prepare it with great care and very carefully as usual. He decided to resume his summary sheet. He needed to finish writing up the last ten sheets today in order to spend his remaining time reading and revising all sheets before the D-Day. He opened the blue file containing of all his courses. He underlined the main ideas with a green highlighter. Then, he took index cards out of a metallic locker.

Satisfied goal. After he had finished writing up all his cards, Nicolas remembered he had to meet the other members of the rock group at the garage to practise. He should leave now not to be late. He was happy to have finished to write up his notes before the practising.

Unsatisfied goal. Before he had finished to write up all his cards, Nicolas remembered he had to meet the other members of the rock group at the garage to practise. He should leave now not to be late. Nicolas would have to resume and finish writing up his notes after the practising.

Filler. He picked up his guitar and rushed to join the rest of the group who was waiting him. As soon as he arrived, Nicolas hastened to link his guitar up with an amp. So, they were able to begin practising. After more than two hours practising, each of them returned home. He was at home and decided to play computer games for a moment. $\mathrm{He}$ sat down at his desk, shoved the blue file and installed the games (distant overlap 
condition). He sat down at his desk, shoved the index cards and installed the games (close overlap condition).

Target sentences. He was completely absorbed in his game and he played for two hours. Then, he decided to talk with his girlfriend on a direct dialogue site.

Conclusion. He lifted his computer, logged on network and talked with her for a long time. The time displayed midnight on the alarm, Nicolas decided to go to bed.

N.B.: The contextual cues used in overlap conditions are in italics.

Examples of Texts in FrenchTexte 1. Terminer de rédiger ses fiches

Introduction. Nicolas est un étudiant en licence d'histoire dans une université de Paris. Il est aussi passionné de musique et fait partie d'un groupe de rock. Nicolas était un étudiant extrêmement sérieux et il ne manquait jamais un cours. Son examen était prévu dans cinq jours, il avait l'intention de le préparer avec beaucoup de soins et d'attention, comme d'habitude. Il décida donc de reprendre ses fiches de synthèse. Il devait terminer de rédiger les dix dernières fiches aujourd'hui de sorte à avoir encore un peu de temps pour toutes les relire et les réviser avant le jour $J$. Il ouvrit le classeur bleu dans lequel étaient ses cours. Il souligna les idées essentielles à l'aide d'un fluo vert. Il sortit, ensuite, de son casier métallique, des feuilles cartonnées.

But Satisfait. Après qu'il eût fini de rédiger toutes ses fiches, Nicolas se souvint qu'il avait rendez-vous au garage pour répéter avec les autres membres du groupe. Il devait partir maintenant pour éviter d'être trop en retard. Il était content d'avoir pu terminer de rédiger ses fiches avant la répétition.

But non satisfait. Avant qu'il n'eût fini de rédiger toutes ses fiches, Nicolas se souvint qu'il avait rendez-vous au garage pour répéter avec les autres membres du groupe. Il devait partir maintenant pour éviter d'être trop en retard. Il décida donc qu'il continuerait et finirait de rédiger ses fiches après la répétition.

Remplissage. Il attrapa sa guitare et se précipita rejoindre le reste du groupe qui l'attendait. En arrivant, Nicolas s'empressa de brancher sa guitare et de l'accorder. Ils purent ainsi commencer la répétition. Après deux bonnes heures de répétition, chacun repartit chez soi. En rentrant, Nicolas voulut jouer quelques instants avec sa console de jeu.

Réinstallation du contexte. Il s'assit à son bureau, poussa le classeur bleu et installa la console de jeu (condition chevauchement proche). Il s'assit à son bureau, poussa les feuilles cartonnées et installa la console (condition chevauchement éloigné).

Phrases cibles. Il était tellement absorbé par le jeu qu'il y joua pendant deux bonnes heures. Il décida ensuite de discuter avec son amie sur un site de dialogue en direct.

Conclusion. Il alluma son ordinateur, se connecta au réseau et discuta longuement avec elle. L'heure indiquée sur le réveil indiquait minuit, Nicolas décida d'aller se coucher.

Texte 2. S'acheter une robe de soirée

Introduction. Nathalie est juge d'instruction. Elle était attendue, ce soir, à un gala de bienfaisance auquel le maire l'avait conviée avec insistance. Elle devait absolument s'acheter une jolie robe de soirée car elle n'en avait plus qui soit à sa taille et elle tenait à être élégante. Elle disposait d'une heure vacante avant son audience de l'après midi. Nathalie alla dans une boutique de mode qu'elle connaissait bien. Cette boutique était 
située à proximité du tribunal, dans une rue piétonne. Elle essaya plusieurs modèles élégants. Elle choisit une toilette de soie malgré son prix onéreux.

But Satisfait. Elle venait d'acheter sa robe de soirée quand son téléphone professionnel tinta. C'était un SMS de son assistant, lui disant de le rappeler de toute urgence. Elle prit sa robe de soirée soigneusement emballée et s'empressa de sortir du magasin pour appeler.

But non satisfait. Elle n'avait pas encore acheté de robe de soirée quand son téléphone professionnel tinta. C'était un SMS de son assistant, lui disant de le rappeler de toute urgence. Elle s'empressa de sortir de la boutique pour répondre. Elle s'occuperait de la robe après son appel.

Remplissage. Son assistant l'informait que de nouvelles pièces venaient d'être fournies sur le dossier de l'affaire qui passait en jugement cette après-midi. Il souhait donc la prévenir de ces pièces avant l'audience. Nathalie demanda à son assistant le contenu de ces pièces. Nathalie se rendit compte que ces pièces n'apportaient rien de nouveau au dossier.

Réinstallation du contexte. Tout en discutant, Nathalie fit les cent pas devant la boutique de mode (condition chevauchement éloigné). Tout en parlant, elle ne put s'empêcher de penser aux prix de la toilette de soie (condition chevauchement proche).

Phrases cibles. Nathalie raccrocha et décida sans plus attendre de se rendre au tribunal. Maîtrisant le dossier, elle était sûre que l'audience se passerait bien.

Conclusion. L'audience terminée, elle rentra chez elle pour se préparer. Le maire ne manqua pas de la remercier d'être venue.

Texte 3. Acheter un magnifique bouquet de fleurs

Introduction. Julien est un jeune homme de 28 ans. Il était adoré par sa mère qui était toujours aux petits soins pour lui. Sa mère l'avait invité à déjeuner le jour de la Fête des Mères. Julien voulait absolument lui acheter un magnifique bouquet de fleurs pour lui témoigner son affection. Vers midi il quitta sa chambre de bonne et dévala l'escalier. Il alla dans la zone commerciale. Il s'arrêta chez un fleuriste pour y regarder de splendides roses exposées dehors.

But Satisfait. Il acheta et repartait avec son bouquet de fleurs à la main quand il se rappela qu'il avait dit à sa mère qu'il s'occuperait du dessert pour le déjeuner. Il décida donc de se rendre dans une pâtisserie qui bénéficiait d'une très bonne réputation pour y acheter un gâteau.

But non satisfait. Il n'avait pas encore acheté son bouquet quand il se rappela qu'il avait dit à sa mère qu'il s'occuperait du dessert pour le déjeuner. Il décida donc de se rendre dans une pâtisserie qui bénéficiait d'une très bonne réputation pour $\mathrm{y}$ acheter un gâteau. Il ne lui resterait ensuite plus qu'à acheter les fleurs.

Remplissage. Il choisit un framboisier qui lui semblait très appétissant. La dernière fois qu'il avait mangé un framboisier, il l'avait acheté dans cette boulangerie. Il savait que ce gâteau était apprécié tant par sa mère que par son père. Il avait toutefois hésité à prendre des petits fours qui étaient la spécialité de la maison. Julien paya le framboisier. 
Réinstallation du contexte. Ensuite, Julien retourna chez lui, il passa devant de splendides roses (condition chevauchement proche). Ensuite, Julien prit rapidement le chemin de sa chambre de bonne (condition chevauchement éloigné).

Phrases cibles. Arrivé chez lui, il prit ses clefs de voiture et fonça chez ses parents. Avant de rentrer chez ses parents, il alla s'acheter des cigarettes.

Conclusion. Il se lava ensuite les mains et dégusta le repas préparé par sa mère. Puis la famille passa dans le séjour où ils discutèrent longuement.

Texte 4. Louer des skis

Introduction. Guillaume adorait les sports d'hiver. Cette année, il avait pris une semaine de vacances afin de retourner skier dans les Alpes. Il arriva dans la station à 17 heures. Ensuite, il alla à l'agence immobilière pour récupérer les clés du studio qu'il avait loué. Il défit ses affaires et s'installa rapidement. Comme il commençait à faire nuit, Guillaume décida d'aller immédiatement louer une paire de skis pour pouvoir dévaler les pistes dès l'ouverture, le lendemain. Il se rendit dans une boutique de sport spécialisée en location de matériel. Il essaya plusieurs modèles de skis. Sur les conseils éclairés du vendeur, il choisit une paire légère de skis paraboliques.

But non satisfait. Avant qu'il n'ait pu régler la location de ses skis, une violente tempête de neige éclata et provoqua une coupure d'électricité. Après quinze minutes passées dans le noir, Guillaume sortit de la boutique et traversa la rue pour profiter de la lueur des lampes torches d'un restaurant. Il repasserait prendre ses skis une fois que l'électricité serait rétablie.

But Satisfait. Alors qu'il venait de régler la location de ses skis, une violente tempête de neige éclata et provoqua une coupure d'électricité. Après cinq minutes passées dans le noir, Guillaume sortit de la boutique et traversa la rue pour profiter de la lueur des lampes torches d'un restaurant. Il déposa ses skis à l'entrée du restaurant et attendit le retour de l'électricité.

Remplissage. Peu après, la lumière revint. La tempête avait pris fin aussi vite qu'elle avait commencé. Guillaume se dit qu'il n'aurait pas aimé se trouver sur les pistes à ce moment là, il avait toujours peur de se retrouver bloqué seul dans le froid.

Heureusement pour lui, la météo devait être plus clémente pour les jours à venir.

Réinstallation du contexte. Guillaume retraversa la rue et passa devant la boutique de sport (condition chevauchement éloigné). Guillaume retraversa la rue en pensant aux skis paraboliques (condition chevauchement proche).

Phrases cibles. Guillaume s'arrêta devant une supérette pour s'acheter une crème solaire. Il se rendit ensuite dans son studio pour se préparer un bon petit plat.

Conclusion. Il se prépara une tartiflette accompagnée de quelques tomates. Après le dîner, il regarda un guide qu'il avait pris à l'office du tourisme.

Texte 5. Commander un canapé sur Internet

Introduction. Carole venait d'acheter une jolie maison dans laquelle elle s'est installée depuis peu. De manière à fêter cet événement avec ses amis, Carole avait fixé une date pour sa pendaison de crémaillère. Elle devait investir d'urgence dans un canapé en cuir neuf car le sien était déchiré, abîmé et surtout très inconfortable. Détestant côtoyer la foule dans les boutiques, Carole décida de commander un canapé sur Internet. Carole alluma donc son ordinateur portable pour se connecter sur le réseau Internet. Elle utilisa 
Google comme moteur de recherche pour trouver les sites d'achat en ligne. Après une longue recherche, elle finit par jeter son dévolu sur un canapé de cuir vert.

But non satisfait. Avant qu'elle n'eût validé son bon de commande dûment complété, Carole entendit le téléphone sonner dans la pièce voisine. Elle se leva, quitta son bureau pour aller répondre. Elle validerait la commande de son canapé une fois la communication terminée.

But Satisfait. Un moment après qu'elle eût validé son bon de commande dûment complété, Carole entendit le téléphone sonner dans la pièce voisine. Alors qu'elle se levait pour aller répondre, la confirmation de la commande de son canapé lui parvenait. Elle quitta son bureau pour aller répondre.

Remplissage. Au téléphone, une de ses collègues l'informait qu'en raison d'une grève totale des transports, les bureaux où elles travaillaient seraient fermés le lendemain. Carole remercia sa collègue pour l'information. Carole était contente d'avoir été prévenue de la fermeture des bureaux. Pendant une quinzaine minutes, les deux collègues discutèrent de choses et d'autres. Après avoir raccroché, elle retourna à son bureau.

Réinstallation du contexte. Carole s'assit et se représenta son séjour avec le canapé de cuir vert (condition chevauchement proche). Carole s'assit et vit que son ordinateur portable s'était mis en veille (condition chevauchement éloigné).

Phrases cibles. Elle éteignit son ordinateur et le rangea dans sa mallette de transport. Elle se mit ensuite à trier les différents papiers éparpillés sur son bureau.

Conclusion. Elle tomba sur sa dernière facture de téléphone qu'elle devait régler. Le temps qu'elle passait sur Internet gonflait le montant de ses factures.

Texte 6. Réserver des places de théâtre

Introduction. Marc, chirurgien-dentiste, voulait faire une surprise à sa femme pour leur anniversaire de mariage. Ce matin, il était seul à la maison et n'avait pas de patients avant l'après midi. C'était le moment propice pour trouver un cadeau. Marc se rappela que sa femme, qui adorait le théâtre, lui avait parlé plusieurs fois d'une pièce. Marc se dit que deux places pour cette pièce constituaient le cadeau idéal. Marc prit le Programme des Spectacles, chercha où se jouait la tragédie grecque et nota le numéro de téléphone du théâtre.

But satisfait. Il venait de réserver deux fauteuils et allait reposer son téléphone lorsque ce denier sonna.

Son ami Paul le prévenait qu'il allait arriver en urgence à son cabinet. La réservation des places étant faite, il attendit la venue de son ami.

But non satisfait. Il s'apprêtait à réserver deux fauteuils et allait saisir son téléphone lorsque ce denier sonna. Son ami Paul le prévenait qu'il allait arriver en urgence à son cabinet. Il ferait la réservation des places après avoir soigné son ami. Il attendit sa venue.

Remplissage. Paul arriva rapidement. Il avait atrocement mal aux dents. Marc le conduisit jusqu'au cabinet dentaire qui se trouvait au rez-de-jardin de la maison. Paul avait un bel abcès, consécutif à carie non soignée. Après une bonne demi-heure de soins, Marc libéra son ami, rangea le cabinet, puis regagna le séjour. 
Réinstallation du contexte. Il feuilleta le programme des spectacles pour jeter un œil aux concerts (condition chevauchement éloigné). Il cacha le numéro de téléphone du théâtre au fond de sa poche de veste (condition chevauchement proche).

Phrases cibles. Lui restant un peu de temps avant le premier patient, Marc se prépara un plat. Avant de retourner travailler, il se détendit au soleil dans le jardin.

Conclusion. L'après midi s'annonçait chargée, mais il espérait ne pas finir trop tar. Une fois sa journée finie, Marc se hâta d'aller retrouver sa femme.

Texte 7. Aller voir un film qui a reçu la Palme d'or

Introduction. Edouard, jeune homme cinéphile, ne manquait jamais de visionner la sélection du festival de Cannes. Le film « Le doux été » avait reçu la Palme d'or. Les critiques étaient toutes excellentes et Edouard tenait vraiment à voir ce film dès sa sortie en salle. Le jour venu, il se précipita dans un cinéma sur les boulevards parisiens. Comme il était en avance, il jeta un œil aux photos exposées dans la vitrine du hall. Il fit la queue au guichet tenu par une jeune fille.

But non satisfait. Alors qu'il approchait du guichet, une bande de saltimbanques vint le prendre à partie pour leur spectacle ambulant. Edouard se prit au jeu et adopta des positions invraisemblables pour donner du fil à retordre au mime de la troupe. Cette situation lui rappelait une scène de la bande annonce du film, qu'il irait voir à la prochaine séance de la soirée.

But satisfait. A la fin de la séance, alors qu'il repassait près du guichet et quittait le cinéma, une bande de saltimbanques vint le prendre à partie pour leur spectacle ambulant. Edouard se prit au jeu et adopta les positions les plus invraisemblables possibles pour donner du fil à retordre au mime de la troupe. Cette situation lui rappelait une scène du film qu'il venait de voir.

Remplissage. Le mime de la troupe singea Edouard avec beaucoup d'humour et de brio. Edouard, tant bien que mal, releva le défi de copier à son tour chaque mouvement du mime. Autour d'eux, un nombre de plus en plus important de passants s'arrêtaient et riaient du comique de la situation : tel était pris qui croyait prendre. Enfin, la troupe s'en alla.

Réinstallation du contexte. Edouard regarda la troupe qui remontait les boulevards parisiens (condition chevauchement éloigné). Edouard regarda la troupe et croisa la jeune fille du guichet (condition chevauchement proche).

Phrases cibles. Comme il se faisait tard, Edouard se mit à la recherche d'un taxi. Quelques minutes plus tard, un taxi libre passa et Edouard l'arrêta.

Conclusion. Edouard était heureux car il avait passé une soirée bien agréable. En cherchant le sommeil, il pensa au programme de la journée à venir.

Texte 8. Confirmer la réservation d'un billet d'avion

Introduction. Marie travaille pour une agence de publicité. Ce soir, elle était restée chez elle pour avancer sur une maquette qu'elle devrait remettre, à son retour de vacances. Par ailleurs, elle devait à tout prix, avant 23 heures, confirmer la réservation de son billet d'avion. Si elle ne le faisait pas, elle ne bénéficierait pas de la réduction sur le prix du billet. Elle risquait aussi de ne pas avoir de place pour la date de son départ en vacances. Elle s'assit alors dans son fauteuil en cuir, prit l'annuaire téléphonique et saisit le téléphone sans fil. 
But satisfait. Après avoir confirmé sa réservation, elle reçut un coup de fil de son patron qui l'avertissait que la maquette devait être terminée pour le lendemain matin. Marie était obligée de finir son travail ce soir. Comme elle avait confirmé sa réservation, elle se remit immédiatement sur la maquette.

But non satisfait. Avant d'avoir confirmé sa réservation, elle reçut un coup de fil de son patron qui l'avertissait que la maquette devait être terminée pour le lendemain matin. Marie était obligée de finir son travail ce soir. Elle ferait la confirmation de sa réservation plus tard dans la soirée car elle devait se remettre immédiatement sur la maquette.

Remplissage. Marie commença par choisir plusieurs couleurs pour sa maquette. Elle fit une première version en noir et blanc. Ensuite, elle y ajouta différentes nuances de rouge et de violet. Pensant que l'entreprise n'aimerait peut-être pas ces couleurs vives, elle prépara d'autres versions à base de couleurs pastelles. Enfin, elle en avait fini avec son travail.

Réinstallation du contexte. Marie quitta son bureau et mit son téléphone sans fil à charger sur sa base (condition chevauchement proche).

Marie quitta son bureau et resta quelques instants dans son fauteuil en cuir (condition chevauchement éloigné).

Phrases cibles. Fatiguée de sa journée, Marie décida d'aller rapidement se coucher. Elle se démaquillât le visage, mit son pyjama et se glissa sous la couette.

Conclusion. Marie espérait que sa production plairait à son patron et à leur client. Elle s'endormit rapidement en passant à ses vacances prochaines.

\section{ABSTRACTS}

The resonance model framework (Myers \& O'Brien, 1998) assumes a passive, fast-acting resonance process as the basic mechanism for retrieving prior information. This process is triggered as soon as a semantic and contextual overlap is present between information currently processed and information stored in long term memory. We investigated the hypothesis that a specific overlap, related to the temporo-causal structure of the text, may influence the resonance process. Results stress the importance of contextual overlap for the resonance process and highlight the role of text structure in the manipulation of the overlap.

Le modèle de résonance (Meyers \& O'Brien, 1998) suppose un processus de résonance passif en tant que mécanisme principal de récupération des informations traitées antérieurement et stockées en mémoire à long terme. Ce processus est déclenché par la présence d'un chevauchement sémantique et contextuel entre des informations en cours de traitement et des informations en mémoire à long terme. Nous formulions l'hypothèse selon laquelle un chevauchement contextuel spécifique, en lien avec la structure temporo-causale des textes, influencerait le processus de résonnance. Les résultats soulignent l'importance du chevauchement contextuel sur le processus de résonance et du rôle de la structure des textes dans la manipulation du chevauchement. 
INDEX

Keywords: comprehension, overlap, text structure

Mots-clés: résonance, chevauchement, structure des textes

\section{AUTHORS}

\section{CATHERINE JOVET}

Corresponding author: Laboratoire ACCOLADE Université de Reims Champagne-Ardenne, 57 rue Pierre Taittinger, 51096 Reims Cedex, France. - Phone: +33-06-62-62-02-96. - Email: catherine.jovet@laposte.net

\section{JEAN-BAPTISTE LÉGAL}

Université de Paris X, Nanterre - Laboratoire de Psychologie Sociale des Cognitions

\section{SANDRA JHEAN-LAROSE}

IUFM de Paris et EPHE - Équipe CHArt : Cognition Humaine et Artificielle GUY DENHIÈRE

CNRS- EPHE Équipe CHArt : Cognition Humaine et Artificielle 